\title{
Quality Higher Education and Students' Perception: A Study on Private Universities of Bangladesh
}

\section{Md. Mizanur Rahman}

Senior Lecturer, Department of Business Administration, Metropolitan University, Sylhet, BANGLADESH

\begin{abstract}
This is a pragmatic study conducted to explore the quality higher education and students' perception towards the private universities in Bangladesh. This study examines the relationship between the quality higher education and students' perception using a structured questionnaire. A total number of 500 senior undergraduate and graduate level students from ten selected private universities in Bangladesh were taken as sample for conducting the study. The finding of this study discloses that the quality higher education is a dynamic factor that ensures the students' perception. It also shows that quality higher education can create positive students' perception towards the private universities in Bangladesh. Reliability, Responsiveness, Competence, Tangibility, Courtesy, Goodwill \& Image, Empathy, Security and Costs are the dimensions of quality higher education. To quantify the variables a five point "Likert- type" scale has been used in this paper. The researcher conducted various analyses such as Multiple Regression Analysis, Descriptive Analysis, and ANOVA and identified a numerous key findings as to the students' perception towards the quality higher education.
\end{abstract}

Key Words: Bangladesh, Higher education, Private University, Students' perception, and Quality.

JEL Classification Code: I20; I23

\section{INTRODUCTION}

K.H. Rezwanul et al., 2009 mentioned "students are considered as the customer of a university especially in a private university". Every customer's in the world focus on quality products. As students are customer, their perception towards the university is to get quality education. So university should ensure the quality higher education. Numerous studies should have been conducted on quality higher education and students' perception. But limited research has been done in this area in context of Bangladesh. Higher education, the important parts of education system is provided through public and private universities. The significant purposes of higher education are to generate the new knowledge, explore research works on different social and development issues, anticipate the needs of the economy and prepare highly skilled workers. In these contexts, higher education should be standard, welfare and sustainable development oriented. The present paper intends to analyze the students' perception toward quality higher 
education at private universities in Bangladesh. Most of the students of Bangladesh try to complete their higher education from public universities. But only public universities could not fulfill to meet or accommodate the demand of the students. Due to this reason private universities have started their journey in Bangladesh under the private university Act 1992. Up to the year 1996 there were only sixteen private universities in Bangladesh (Ashraf et al, 2009), the number has reached fifty four at present (BDNEWSCORNER 2012). The public and private universities are responsible to provide higher education but due to profit-making motive of private universities and lack of awareness of public universities, it is quite impossible to ensure quality education (Uddin, et al, 2011). In terms of quality in education, the World Bank (1995: 46) puts forth the following concept: Quality in education is difficult to define and measure. An adequate definition must include student outcomes. Most educators would also include in the definition the nature of the educational experiences that help to produce thus outcomes.

So, what is Quality Education? As defined by UNESCO (2001), "A renewal of higher education is essential for the whole society to be able to face up to the challenges of the twenty-first century and to ensure its intellectual independence. Quality higher education needs to be restored to create and advance knowledge, educate and train responsible, enlightened citizens and qualified specialists, without whom no nation can progress economically, socially, culturally or politically." How does this translate in terms of quality of graduates produced by Bangladesh universities? As a developing nation, Bangladesh needs graduates who can think independently and are willing to strive and experiment with new ways to bring Bangladesh out of the vicious circle of poverty. The question is, will the current education delivery model, which can at best be classified as following the "behaviorism" model, produce such graduates? Sadly, this model is even applied to language learning. Can learning by rote produce independent thinkers? If not, what needs to be done?

\section{Methodology}

\section{Sources of data}

For conducting this research both primary and secondary data have been used .To collect primary data, a structured questionnaire was designed in light of the objectives of the research. Students from different groups from ten selected universities were asked to fill up the questionnaire. Secondary data were collected from different books, publications, research studies, journals, articles, and websites.

\section{Sample size and location}

The sample of the study covers the students from ten selected private universities in Bangladesh. A sample of 500 students (male and female) selected purposely from some private universities. The study was limited to ten private universities of Dhaka and Sylhet City. According to the press briefing of the Ministry of Education of Bangladesh published in the daily Prothom Alo (2010) the private universities of Bangladesh have been classified into three groups resembling green, yellow and red signs. For the purpose of the study ten universities were selected representing three from the green group, four from the yellow group and three from the red group.

\begin{tabular}{|c|c|l|c|c|}
\hline $\begin{array}{c}\text { Assembling } \\
\text { Sign }\end{array}$ & No & \multicolumn{1}{|c|}{ Name of the University } & City & $\begin{array}{c}\text { Year of Estab } \\
\text { lishment }\end{array}$ \\
\hline \multirow{3}{*}{ Green } & 1. & $\begin{array}{l}\text { Ahsanullah University of Science } \\
\text { and Technology (AUST) }\end{array}$ & Dhaka & 1995 \\
\cline { 2 - 5 } & 2. & BRAC university (BRACU) & Dhaka & 2001 \\
\cline { 2 - 5 } & 3. & North South University(NSU) & Dhaka & 1992 \\
\hline
\end{tabular}




\begin{tabular}{|c|c|l|c|c|}
\hline \multirow{4}{*}{ Yellow } & 4. & $\begin{array}{l}\text { United International } \\
\text { University(UIU) }\end{array}$ & Dhaka & 2003 \\
\cline { 2 - 5 } & 5. & $\begin{array}{l}\text { Northern University of } \\
\text { Bangladesh (NUB) }\end{array}$ & Dhaka & 2002 \\
\cline { 2 - 5 } & 6. & Metropolitan University(MU) & Sylhet & 2003 \\
\cline { 2 - 5 } & 7. & $\begin{array}{l}\text { Daffodil International } \\
\text { University(DIU) }\end{array}$ & Dhaka & 2002 \\
\hline \multirow{3}{*}{ Red } & 8. & Leading University(LU) & Sylhet & 2002 \\
\cline { 2 - 5 } & 9. & $\begin{array}{l}\text { Sylhet International } \\
\text { University(SIU) }\end{array}$ & Dhlhet \\
\cline { 2 - 5 } & 10. & $\begin{array}{l}\text { World University of } \\
\text { Bangladesh(WUB) }\end{array}$ & 2003 \\
\hline
\end{tabular}

Source: The Daily Prothom Alo, 13th December, 2010

\section{Mathematical ToOLS}

We also decided to use Z-test,

We know that, $Z=\frac{\frac{\mathrm{x}}{\mathrm{n}}-\mathrm{p}}{\sigma \mathrm{P}}$

$\mathrm{Z}=$ Calculated $\mathrm{Z}$ value

$x=$ No. of sample success (No. of respondents supporting $\mathrm{H}_{0}$ )

$\mathrm{P}=$ Hypothesized population (Probability for $\mathrm{H}_{0}$ Acceptance)

$\sigma \mathrm{P}=$ Standard error of the population.

The level of significance for the test is $95 \%$. This makes the tabulated $\mathrm{Z}$ to be \pm 1.64 .

\section{DEMOGRAPHIC INFORMATION}

The demographic information of the students is designed on the basis of four important variables: Age, Gender, Department and Year of study.

\begin{tabular}{|l|c|c|c|}
\hline \multicolumn{1}{|c|}{ Variable } & Particulars & Frequency & Percentage \\
\hline Age & Less than 19 & 20 & $04 \%$ \\
& $19-24$ & 305 & $61 \%$ \\
& $24-29$ & 35 & $07 \%$ \\
& More than 29 & 160 & $32 \%$ \\
\hline Gender & Male & 378 & $75.6 \%$ \\
& Female & 122 & $24.4 \%$ \\
\hline Department & Business & 254 & $50.8 \%$ \\
& Humities \&Arts & 148 & $29.6 \%$ \\
& Science & 184 & $36.8 \%$ \\
\hline Year of & First Year & 50 & $10 \%$ \\
Study & Second Year & 100 & $20 \%$ \\
& Third Year & 180 & $36 \%$ \\
& Final Year and Above & 170 & $34 \%$ \\
\hline
\end{tabular}


The result on respondent's age states that almost $61 \%$ students' age range between $19-24$ years and $32 \%$ of the students are in the range of more than 29 years generally they are the students of MBA, MSC and MA program. The sample include $75.6 \%$ male and $24.4 \%$ are female students. Out of 500 students $50.8 \%$ are business students, $36.8 \%$ are science students and 29.6 are humanities and arts students. Majority of the students in this study are third year followed by final year and above, second year and first year.

\section{LITERATURE REVIEW}

Perception especially the positive perception of the students is very important for the development of higher education in private universities. University authority should emphasis on quality higher education to create the positive perception. Pariseau and McDaniel (1997), emphasized that the feedback from students is very important aspect for several reasons to improve quality of programs that will be helpful for the educators to improve their level of service quality to create a positive image in the mind of students or positive perception about students. Anderson (1995) and Susan (1997), considered the feedback of students very important especially for providing educators the opportunity for the enhancement of quality of services and enabled them to create positive perception in the minds of the students about the institutes. Deming (2000), suggested that like as manufacturing sector of the economy the service quality factor should be applied in the education sector. Alves and Raposo (2010), said that the perceived quality is the factor which create positive image in the mind of students which ultimately caused of student's satisfaction. Cuthbert (1996), explained the nature of the higher education service quality as classical services. He said that it's an intangible and heterogeneous type of service which produced and consumed at the same time. Due to its characteristics of perishability, it meets the criterion of inspire ability and consider students as participant in the delivery process. Cubillo et al., (2006), discussed five factors that most of the student consider while selecting the institute. Three out of them are external and two are internal which directly related to the institute. The external factors were as the personal reasons, previous experiences discussed by the alumni and the location of the program. But the most related to the institute were the image of the institution and the perceived quality of the study programs. He also suggested that the importance of these internal factors was not ascertained but the institution must maintain their relative image and perceived quality for sustainable competitive position among competitors. Oldfield and Baron, (2000), considered the students level of satisfaction as an important source of the institute for the maintenance of its competitive position and financial stability.

Generally positive perception of the students towards quality higher education in a private university depends on some crucial factors such as infrastructure of the university (library facility, hostel facility, computer lab facility, class room facility, and laboratory facility), quality of faculty members, behavior of administrative staffs, and location of the campus and so on. Mamun and Das (1996), undertook a study and pointed towards some other attracting factors such as library facilities, laboratory facilities and internship assistance for students as the key factors of students' choice of private universities. Zahid, Chowdhury and Sogra (2009), and mentioned and extensive qualitative study of performance of business education in Bangladesh and identified the course system , quality of teaching, medium of instruction, campus size and location, accommodation for the students, campus facilities such as auditorium, parking, canteen, indoor and outdoor parking facilities as the factors of satisfaction.

There are almost fifty four private universities in Bangladesh (BDNEWSCORNER 2012).The growing trend as well as competition has stood up recently. It is good news for the students; 
private universities are trying to compete with each other to provide quality higher education. Because in earlier it is said that quality higher education can create the positive perception on the students mind. Beaver (1994), noted the trend of increased competition among universities and option available for students to search and select universities of their own choice across the globe. Many of the colleges administrators for quality education implemented total quality management in their practices to assure the customers of the higher education they were been served in an appropriate manner. Abouchedid and Nasser (2002), said that the service quality to be considered as an unavoidable matter of attention for the successfulness and maintenance of competitive position among the higher education institutes. Md. Abu Naser says in his study regarding education quality of private universities in Bangladesh "The emergence and the growth of the private universities in Bangladesh have taken a unique shape in recent years and have introduced American system in country's higher education. They are playing an important role in spreading the opportunities of higher education and have a role to develop competent and market oriented human resources. But in recent years a widespread allegations were raised against PUs that some are selling certificates, easy-to-get degrees, very poor teaching qualities, poor infrastructure, high tuition fees, etc."

\section{THEORETICAL FrameWORK AND HyPOTHESES}

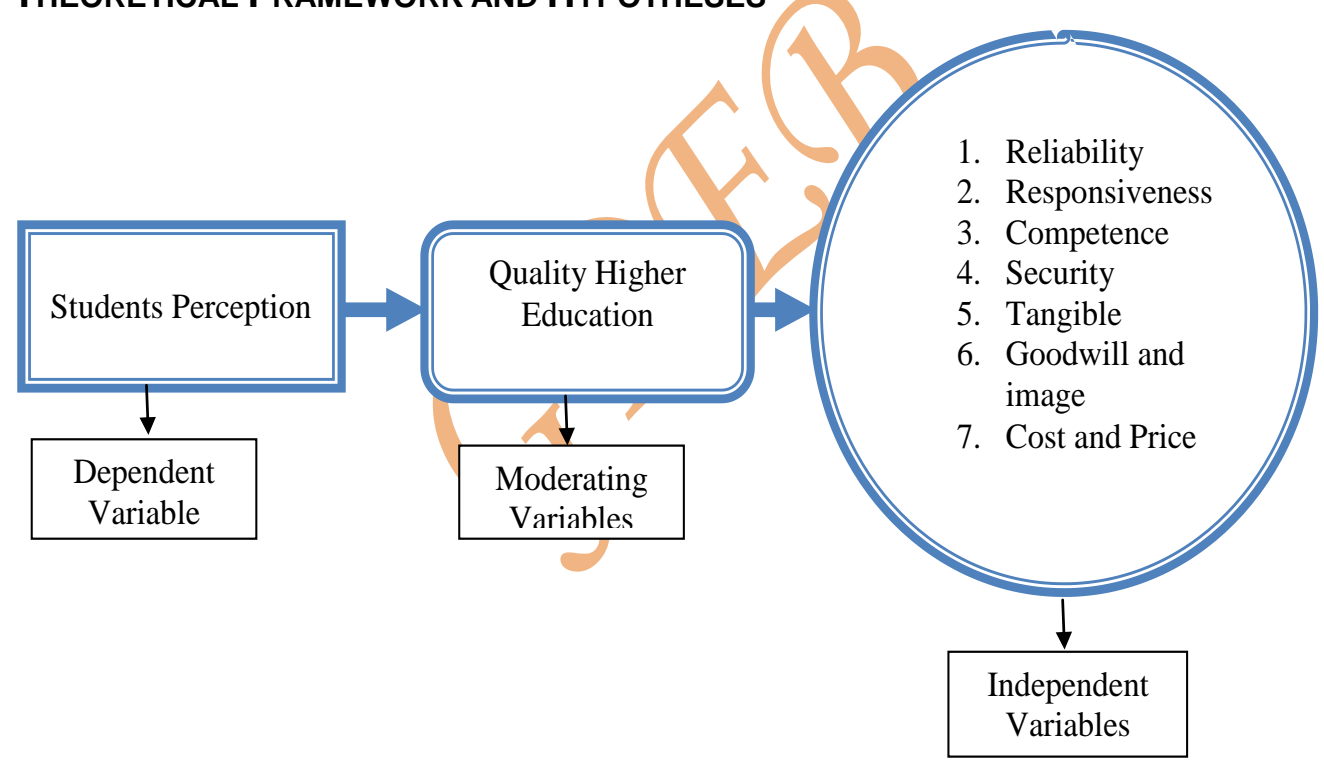

\begin{tabular}{|ll|}
\hline Reliability & Consistency of performance and dependability \\
\hline Responsiveness & Willing and readiness of staff to provide service. \\
\hline Competence & Required skills and knowledge to perform the service. \\
\hline Security & Freedom from danger, risk or doubt. \\
\hline Tangible & Physical evidence of the service. \\
\hline $\begin{array}{l}\text { Goodwill and } \\
\text { Image }\end{array}$ & $\begin{array}{l}\text { Accreditation, credit transfer facilities, affiliation, } \\
\text { direct branches and franchising. }\end{array}$ \\
\hline Cost and price & Fees to be paid in order to receive the service. \\
\hline
\end{tabular}


Drawing from the above literature review and theoretical framework discussion, the researcher has proposed the following core hypothesis.

H1:"There is relationship between the dimensions of service and quality higher education".

\section{Supportive hypotheses:}

After reviewing the literature the researcher thought that there are four important dimensions which are directly related to the quality of higher education. So the researcher has proposed the following four specific hypotheses.

H1a: There is a relationship between the reliability dimension and quality higher education.

H1b: There is a relationship between the responsiveness dimension and quality higher education.

H1c: There is a relationship between the goodwill and image dimension and quality higher education.

H1d: There is a relationship between the competences dimension and quality higher education.

\section{EMPIRICAL FINDINGS AND ANALYSIS}

\begin{tabular}{|c|c|c|c|c|c|}
\hline No & Dimensions & No & $\begin{array}{c}\text { Factors or Items Relating to Quality } \\
\text { Education }\end{array}$ & Mean & SD \\
\hline \multirow{4}{*}{ D1 } & \multirow{4}{*}{ Reliability } & F1 & Each semester starts at the right time. & 1.05 & .61 \\
\hline & & F2 & Examinations are held at the right time. & 2.21 & 1.05 \\
\hline & & F3 & $\begin{array}{l}\text { My academic and administrative } \\
\text { documents are kept correctly. }\end{array}$ & 1.65 & .77 \\
\hline & & F4 & Results are published timely. & 2.00 & 1.10 \\
\hline \multirow[t]{3}{*}{ D2 } & \multirow{3}{*}{$\begin{array}{l}\text { Responsiven } \\
\text { ess }\end{array}$} & F5 & $\begin{array}{l}\text { My teachers' give me enough time for } \\
\text { understanding the subjects matter. }\end{array}$ & 1.31 & .81 \\
\hline & & F6 & $\begin{array}{l}\text { I also receive the attention from my } \\
\text { teachers' than subject s matter. }\end{array}$ & 2.05 & 1.11 \\
\hline & & F7 & $\begin{array}{l}\text { University staffs are helpful in providing } \\
\text { services. }\end{array}$ & 3.00 & 1.44 \\
\hline \multirow{3}{*}{ D3 } & \multirow{3}{*}{ Competence } & F8 & Teachers' of my university are competent. & 2.25 & 1.50 \\
\hline & & F9 & $\begin{array}{l}\text { Teachers' can make the subjects } \\
\text { understanding to me. }\end{array}$ & 2.31 & 1.51 \\
\hline & & F10 & Teachers' have research expertise. & 3.13 & 1.67 \\
\hline \multirow[t]{3}{*}{ D4 } & \multirow[t]{2}{*}{ Security } & F11 & $\begin{array}{l}\text { The university has necessary measures to } \\
\text { combat fire, electric short circuit and others. }\end{array}$ & 3.87 & 1.81 \\
\hline & & F12 & $\begin{array}{l}\text { It takes necessary action against the } \\
\text { students' conflict. }\end{array}$ & 2.21 & 1.43 \\
\hline & & F13 & $\begin{array}{l}\text { Well-furnished class rooms with modern } \\
\text { teaching aids. }\end{array}$ & 2.61 & 1.75 \\
\hline
\end{tabular}




\begin{tabular}{|l|l|l|l|c|c|}
\hline D5 & Tangible & F14 & $\begin{array}{l}\text { Extra- curricular activates can built the } \\
\text { image of a university. }\end{array}$ & $\mathbf{3 . 5 4}$ & $\mathbf{1 . 8 8}$ \\
\cline { 3 - 6 } & & F15 & $\begin{array}{l}\text { The authorities take proper steps for books, } \\
\text { canteen, recreation, classroom facilities etc. }\end{array}$ & $\mathbf{3 . 0 0}$ & $\mathbf{1 . 4 4}$ \\
\hline \multirow{2}{*}{ D6 } & \multirow{2}{*}{$\begin{array}{c}\text { Goodwill \& } \\
\text { Image }\end{array}$} & F26 & $\begin{array}{l}\text { I have selected this university as it has } \\
\text { goodwill. }\end{array}$ & $\mathbf{2 . 2 5}$ & $\mathbf{1 . 3 6}$ \\
\cline { 3 - 7 } & F17 & The image of the campus buildings. & $\mathbf{2 . 8 7}$ & $\mathbf{1 . 3 3}$ \\
\cline { 3 - 6 } & F18 & $\begin{array}{l}\text { Credit transfer facilities and affiliation of a } \\
\text { foreign University. }\end{array}$ & $\mathbf{2 . 9 0}$ & $\mathbf{1 . 3 5}$ \\
\hline \multirow{2}{*}{ D7 } & \multirow{2}{*}{$\begin{array}{c}\text { Costs \& } \\
\text { Price }\end{array}$} & F19 & $\begin{array}{l}\text { The service I receive from this university is } \\
\text { quite equal to fees I pay. }\end{array}$ & $\mathbf{3 . 0 0}$ & $\mathbf{1 . 4 4}$ \\
\cline { 3 - 7 } & F20 & $\begin{array}{l}\text { Each semester the university gives tuition } \\
\text { fees waivers to sum of our students. }\end{array}$ & $\mathbf{2 . 8 5}$ & $\mathbf{1 . 3 5}$ \\
\hline
\end{tabular}

\section{EXPLANATION}

The results of the descriptive statistics are described based on the five "Likert-type" scaling technique where 1as strongly positive, 2 as positive, 3 as neither positive nor negative, 4 as negative and 5 as strongly negative. The descriptive table consists of seven dimensions and twenty factors. The researcher has discussed each dimension with its factors separately.

\section{Reliability}

The dimension reliability has four factors: each semester starts at the right time, examination are held at the right time, my academic and administrative documents are kept correctly and results are published timely. The mean score of these factors 1.05 to 2.00 , which states that students' perception are generally between strongly positive and positive. The standard deviations are between .61 and 1.10 for these factors. It indicates students' perception towards the reliability dimension is positive.

\section{Responsiveness}

The dimension responsiveness has three factors: my teachers' give me enough time for understanding the subjects matter; i also receive the attention from my teachers' than subjects matter university, staffs are helpful in providing services. The mean score of these factors 1.31 to 3.00, which states, students' perception generally between strongly positive and neither positive nor negative. The standard deviations are between .81 and 1.44 for these factors. The mean 3.00 in terms of the service providing by the university staffs indicates that the perception of the students toward university is not so positive.

\section{Competence}

The dimension competence has three factors: Teachers' of my university are competent, teachers' can make the subjects understanding to me, teachers' have research expertise The mean score of these factors 2.25 and 3.13, which state that students' perception generally between positive and neither positive nor negative.. The standard deviations are between 1.50 and 1.67 for these factors. The mean 3.13 in terms of the teachers' research experience indicates, the perception toward research activities of their teachers 'are not as positive as their expectation because at the time of conducting internship and thesis report the teachers cannot guide them as their expectation.

\section{Security}


The dimension security has two factors: The University has necessary measures to combat fire, electric short circuit and others, it takes necessary action against the students' conflict The mean score of these factors 2.2 and 3.87, which state that students' perception are generally between positive and negative. The standard deviations are between 1.43 and 1.81 for these factors. The mean 3.87 is related to necessary measures to combat fire, electric short circuit and others that indicates students do not have positive perception towards the security system of the university.

\section{Tangible}

The dimension tangible has three factors: Well-furnished class rooms with modern teaching aids,

Extra-curricular activates can built the image of a university, the authorities take proper steps for books, canteen, recreation, classroom facilities etc. The mean score of these factors 2.61 and 3.54, which state that students' perception are generally between positive and negative. The students' perception towards extra- curricular activates the university is not positive along with library and canteen facilities. The standard deviations are between 1.44 and 1.88 for these factors.

\section{Goodwill \& Image}

The dimension Goodwill \& Image has three factors: $\mathrm{i}$ have selected this university as it has goodwill, the image of the campus buildings, credit transfer facilities and affiliation of a foreign university. The mean score of these factors 2.25 and 2.90, which states students' perception generally between positive and neither positive nor negative. The standard deviations are between 1.33 and 1.36 for these factors.

\section{Costs \& Price}

The dimension of costs and price has two factors: the service i receive from this university is quite equal to fees i pay, each semester the university gives tuition fees waivers to sum of our students. The mean score of these factors 2.85 and 3.00, which state that students' perception generally between positive and neither positive nor negative. The standard deviations are between 1.35 and 1.50 for these factors.

\section{TEST OF HYPOTHESIS}

The hypotheses of the study were formulated in terms of null hypothesis (Ho) and alternative hypothesis $(\mathrm{Ha})$. To know the perception the students regarding quality education in private universities of Bangladesh, the following hypothesis is formulated:

Ha: "There is a relationship between the dimensions of service and quality higher education". Ho: "There is no relationship between the dimensions of service and quality higher education".

The question relating to hypothesis was: Do you think quality higher education has a positive relationship with dimension of services?

On the basis of the responses of the 150 respondents following table is designed

\begin{tabular}{|l|c|c|}
\hline \multicolumn{1}{|c|}{ Nature of Responses } & Number of Responses & Percentage \\
\hline Yes & 425 & $85 \%$ \\
\hline No & 75 & $15 \%$ \\
\hline Total collected data(2012) & 500 & $100 \%$ \\
\hline
\end{tabular}

The table shows that, out of 500 students' 425 agreed that quality higher education has a 
positive relationship with the dimension of services. Moreover only 75 students' does not agree that quality higher education has a positive relationship with the dimension of services. Accordingly, only 75 students supported null hypothesis (Ho).

Formulation of the Hypothesis: The researchers formulated the null hypothesis (Ho), that the number of success sample

$\mathrm{X}$ is equal to $75: \mathrm{Ho}=75$

$\mathrm{X}$ is not equal to 75 : $\mathrm{Ha} \neq 75$

$Z==-8.675$ (by using the formula of $Z$ ).

Since Z- calculated value $(-8.675)<Z$ - table value $(-1.64)$. It falls outside the acceptance region. Therefore, the null hypothesis (Ho) is rejected and the alternative hypothesis (Ha) is accepted. Consequently, it can be said that there is a positive relationship with the dimensions of service and quality higher education.

\section{MuLtiple Regression ANALYSiS}

A multiple regression analysis was conducted to test the above mentioned sub-hypothesis. The result of the multiple regression analysis is shown in the table.

\begin{tabular}{|l|c|c|c|}
\hline Dimensions & $\boldsymbol{\beta}$ & $\mathbf{t}$ & $\mathbf{p}$ \\
\hline Reliability & .27 & 2.17 & .45 \\
\hline Responsiveness & .25 & 2.04 & .04 \\
\hline Competences & .23 & 2.00 & .04 \\
\hline Security & .02 & .44 & .34 \\
\hline Tangibility & .03 & .45 & .54 \\
\hline Goodwill and Image & .24 & 2.01 & .042 \\
\hline Price and Costs & .09 & .87 & .49 \\
\hline
\end{tabular}

$\mathrm{R}^{2}=.70$, Adjusted $\mathrm{R}^{2}=.68, \mathrm{~F}(5.99)=42.5, \mathrm{p}=0.05$ Source: By using SPSS-13 Version.

From the table we see that the factors of reliability are positively related with quality higher education $(\beta=.27, p<.05)$ indicating that the higher level of reliability, the higher level of quality education which ensure the students' positive perception towards the private universities in Bangladesh. Responsiveness are positively related with quality higher education $(\beta=.25, \mathrm{p}<.05)$ indicating that the higher level of responsiveness, the higher level of quality education which. Goodwill and image $(\beta=.24, p<.05)$ is positively related to the quality higher education, indicating that the higher level of goodwill and image of the university, the higher level students positive perception. Finally, competence $(\beta=.23, p<.05)$ is positively related to the quality higher education that also indicates, the higher level competence, the higher level of students' positive perception. So the above findings support the hypothesis $\mathrm{H} 1 \mathrm{a}, \mathrm{H} 1 \mathrm{~b}, \mathrm{H} 1 \mathrm{c}$ and $\mathrm{H} 1 \mathrm{~d}$. value of .70 indicated $70 \%$ of the variance in students' perception is explained by the seven dimensions of service quality.

\section{ConcLusion}

The results of the analysis indicate that the students have positive perception towards the quality higher education of private universities in Bangladesh. They agreed with the service quality level provided by the universities except the service provided by the university staffs, security system, extra-curricular activities, quality of food and services level at canteen. They have overall positive perception towards the service quality 
provided by the private universities of Bangladesh. The service quality dimensions as reliability, responsiveness, competence, goodwill \& image, tangibility and costs are significant determinant of service quality for private universities of Bangladesh.

\section{Discussion AND FUtURE RESEARCH}

The students have positive perception of service quality provided by the private universities in Bangladesh. The results of the hypothesis testing by one sample statistics also shows that the service quality dimensions as reliability, responsiveness, competence, tangibility and costs are appears significant. The findings of this research are only focused on the private universities of Dhaka and Sylhet city may not be generalized for the whole Bangladesh. This research contains the service quality dimensions as reliability, responsiveness, competence, goodwill image, tangibility and costs further research can be done by using other dimensions for data collection.

\section{ACKNOWLEDGEMENT}

I would like to mention the contribution of all those who have inspired, influenced and helped me on the way of completing this research paper. First of all, my deepest and sincere gratitude goes to my younger brother Md. Saidur Rahaman, student of Rajsahi University, Rahshahi, and my younger sister Sultana Sumi, student of Metropolitan University who have given me the opportunity to go through the processes of this paper. Both of are the students otherwise I could confer them as my co-researcher but in future I will work with them. I also wish to acknowledge all of my respected teachers of Department of Business Administration for their suggestions and kind co-operations.

\section{REFERENCES}

Abouchedid. K and Nasser, R. (2002), “Assuring quality service in higher education: Registration and advising attitudes in a private university in Lebanon", Quality Assurance in Education, 10(4):198-206

Alves. H and Rapos. M (2010), "The influence of university image on student behavior", International Journal of Educational Management, 24(1), 73 - 85

Andaleeb, S.S. (2003). Rejuvenating the Nation's Higher Education System. Proceeding of the workshop organized by international University of Business Agriculture and Technology, Dhaka, Bangladesh

Beaver, W. (1994), "Is TQM appropriate for the classroom?", College Teaching, 42(3), 111-15

BDNEWSCORNER 2012, 'UGC approved private university list in Bangladesh', 22 January viewed on 20 may2012, http://bdnewscorner.com/ugc-approved-private-university-list-in-Bangladesh

Cubillo José María, Sánchez Joaquín, Cerviño Julio, (2006) "International students' decisionmaking process", International Journal of Educational Management, 20(2), 101-115

Cuthbert,P (1996), "Managing service quality in H.E: is SERVQUAL the answer?" Managing Service Quality Vol. 6(3), 31-35

Deming W.E (2000), “The New Economics: For industry Government, Education”, MIT Press, Cambridge, MAHigher Education", Journal of Managing Service Quality, 48-56. 
Ewing, B. T. (1995). The World Bank Review. Priorities and strategies for education, vol 16, Washington, DC: The World Bank.

Khan R. H., A. H. A. M. Mridha. (2009). BRAC University Journal. Higher Education in Private Universities: A Study on Female Students' Enrollment Behavior. Available: http: //www.google.com/ (May30 2012 at 5.50pm).

Naser M. A. (2010). Education Quality of Private Universities in Bangladesh: faculty resources and infrastructure perspective. Available: http: //www.google.com/ (May30 2012 at 5pm).

Mamun, M. Z.and Das, S: “Total Quality Management for Non-Government Universities of Bangladesh" Proceedings of Annual Convention of Bangladesh Society for Total Quality Mnagement in Association with Department of industrial and Production Engineering, BUET, Dhaka, December 3-4, 1999, pp. 23-29, 1999.

The Daily Prothom Alo 2010, 'Shikha Montrolay Breif: 22 Bishwabidyalayke Lal Shanket', 13th December,2010.

Zahid, J. R. Chowdhury G.M.and Sogra J. (2000) "Present Status and Future Direction of Business Education in Bangladesh" Journal of Business Administration, 26, pp. 11-24. 